\title{
Water-Related Architecture as an Identity Anchor of Chanderi-Madhya Pradesh, India
}

\author{
K. Shubhangi and D. Shireesh
}

\begin{abstract}
Water is life', since time immemorial settlements have sprung up along water-edges and around water sources. Documentation displays records of these ancient step wells, some being as old as 300 - 500 year old are still in good condition structurally and to this date perform its original function of collecting and storing water for dry seasons. Majority of the wells are being used by the natives on a daily basis. Awe-inspiring stepwells found in the region of Chanderi town-Madhya Pradesh in India, have been designed for storing water for performing the function of water conservation giving rise to architectonic typologies from cultural to functional and recreational spaces. Distinct relation between water and building typologies are a unique architectural contribution of Indian Water Architecture to the world. This paper represents exemplaries of water structures of Chanderi having architectural and aesthetical significance.
\end{abstract}

Keywords--- Architectural Study, Water Structures, Conservation Techniques, Water Conservation

\section{INTRODUCTION}

$\mathrm{T}$ RADITIONAL water structures in India is an heritage which is unique to conserve water. Settlements across India have flourished due to good water management and conservation techniques. In India, at some places where rainfall is scarce we see unique architectonic built masterpieces due to varied climatic conditions and geographical terrain. R.S.Morwanchikar [1] in his work in the faculty of water management has put forth strongly that water is life and the entire living world has a deep concern with water without which we cannot survive. Historical evidences help us to understand the significance of water which acts as nucleus where habitation starts to settle with evolution of culture.

Rima [2] briefly highlights her views in this brief paper for her upcoming book sponsored by Infinity Foundation on aspects of the sub-continent's traditional knowledge systems of hydraulic technology and water resource management practices of South-Asia to give them due recognition in the wider world of universal science and technology. Dr.Jutta Jain [3] an art historian has written on the stepwells of Delhi and has discussed exemplaries which are an important component

\footnotetext{
K. Shubhangi, Associate Professor, Marathwada Mitramandal's College of Architecture, Pune, Maharashtra, India. E-mail: shubhangikadam12873@gmail.com, shiroleys@gmail.com

D. Shireesh, Professor Emeritus, Visiting Faculty, Smt. Manoramabai, Mundle's College of Architecture, Nagpur. India. E-mail: profsad@gmail.com

DOI: 10.9756/BIJIEMS.8073
}

of architectural heritage. She has discussed the different roles of stepwells where they were used for numerous purposes such as secular, religious as well as social functions.

Mansee et al. [4] have discussed the case of India at spatial levels which emphasize that there is a strong relation between the value of water resources and how they are managed and governed. By exploratory surveys Shubhangi et al. [5] identified the current situation of stepwells and stepped ponds in the historic city of Bundi-Rajasthan, India which affect the city's landscape. They recommended that the conservation heritage plan should protect the impounded traditional water structures by way of restoration and revival with the help of a proposed plan and section along with design strategies to enhance bio-diversity while maintaining the essence of the historical character. Priya [6] surveyed coastal area of Ratnagiri taluka, Maharashtra, India through archaeological explorations to understand the management of sweet water in the salty area during ancient times, her explorations also revealed a number of wells, tanks and water channels. Her research aimed at studying water tanks located within the vicinity of the temples to analyze whether there existed a relationship between the temples and water tanks. She concluded that not all temples have water tanks located near them due to economic conditions but these temples and water tanks were built due to religious importance and the availability of water resource.

Swati et al. [7] focussed on Ropar Wetland Region as a case study to analyze the current situation and identified that the major threats to the lake is due to human activity resulting in water balance and water quality hence they developed a methodology for development of Environmental Management Plan by using a holistic approach to freshwater management involving local communities. Hasan-Uddin [8] proposes that buildings should be preserved and conserved by technical means and also where there is a need for adaptive reuse of structures. According to him historic buildings contain within them our collective memory which in itself is an integral part of our identity. He further advocates that conservation in itself can be a tool for cultural continuity. Bashir [9] has set guidelines and discussed twenty-five design strategies which serve as indicators to sustainable development under five primary variables for achieving sustainability. The fourth variable on water conservation shows developing water impoundment areas and enhance wetlands throughout the site so that it allows to retain water on site for as long as possible allowing water to percolate into the ground. 
Keshab et al. [10] worked out the potential of revival and modernization of traditional water harvesting systems with three distinct approaches that is the hydrogeological and engineering surveys, village and households surveys and analysis related to the valuation of willingness to pay. Sureshkumar [11] highlighted issues and suggested policy interventions and highlighted the use of groundwater as an important source to meet the present and future water requirements in urban agglomeration of National Capital Territory of Delhi (the capital city of India). Mugdha[12] pointed out the need to put forward strategic frameworks which highlight elements of heritage management practices at local level. Mate et al. [13] dealt with information that has been culled from the epigraphic sources which speak of the construction and maintenance of a large number of small tanks and various aspects of ancient and hydraulic technology as well as the social management of water resources. Anil [14] et al. have reported on the typology of traditional harvesting systems of India and dealt with involvement of the society in the management since ancient times.

Shubhangi et al. [15] put forth exemplaries of water responsive architectonic forms in Chanderi for water conservation which have unique characteristics that contribute to making these water heritage structures unique as these historic assets remain to the present day as living witnesses of their age-old traditions and it is the common responsibility to safeguard them for future generations.

\section{AIM}

- To analyze impounded water structures through architectural study in Chanderi, Madhya Pradesh, India with respect to Spatial Organization.

\section{OBJeCTIVES}

- To investigate and comprehend use of water in traditional Indian architecture and study the diverse manners in which architectural elements respond to water space.

- To study the process and factors of a place and assessing significance involved in utilizing existing water bodies into building typologies with reference to study area-Chanderi, Madhya-Pradesh.

\section{RATIONALE FOR STUDY}

With respect to other semi-arid regions, there are quite a few and varied examples of brilliant architecture found in Chanderi-Madhya Pradesh. As is evident from the primary field studies this core area has been densely dotted with stepwells and stepped-ponds.

\section{Chanderi - Madhya Pradesh}

City development plan of Chanderi [16] describes the historic city of Chanderi and unfolds the water architectural heritage of a vast period ranging from $10^{\text {th }}$ century till present day. The archaeological findings suggest the existence of Chanderi and its surroundings dating back to the prehistoric times which were established by the discovery of a rock shelter with Mesolithic and Chalcolithic paintings (Nannon). Its past is best demonstrated in its historical built heritage, of which a major component is that of its impounded water structures with architectonic forms.

\section{METHODOLOGY}

Understanding the area of study through primary field studies, observation, Grounded Theory (Data Collection, Coding and Memoing), Ethnographic Approach. Inventories, architectural measured drawings used as an indicator to study.

Spatial Organization at Site level - Surveyed and documented the plans, elevation and features of these impounded water structures with respect to Form/Shape, Access, Geometry and architectural features.

\section{STUDY ANALYSIS}

The impounded water conservation structures found in Chanderi can be based on the distinguishing features of the architectural plan and structure which includes the form, circulation, access and volumetric analysis. Architectural analysis of some exemplaries with their drawings plan, sectional-elevations are given. The figures below show detail analysis.

\section{A. Chakla Stepped Pond}

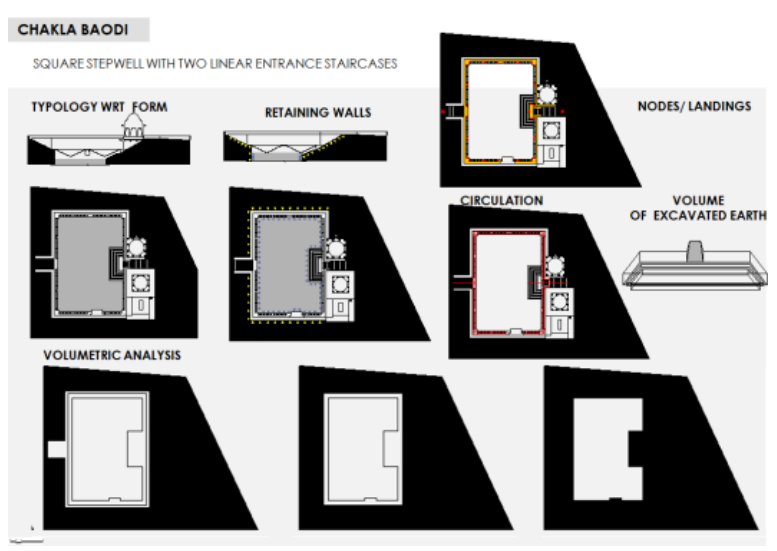

Fig. 1: Drawing of Chakla Stepped Pond, Chanderi

Form-Chakla (Persian wheel was once fitted at one end, hence Chakka or Chakla) the rectangular well admeasuring $35.5 \mathrm{mX} 24 \mathrm{~m}$ is approached from the two opposite ends east and west by crisscrossing steps. A space for water lifting device, such as Persian wheel, was located in the centre of the north face of the well. Pavilion towers on one side act as a directional foci.

Circulation- Narrow ledge surrounding the interiors of the Chakla stepped pond descends towards the water body from two accesses on opposite sides.

Engineering skills- The rectangular wall of the Chakla stepped pond resists the lateral forces from the earth. Pavilion towers sustain thrust pressing against the vertical side walls in the ravine-like stepped corridor. 


\section{B. Musa Stepwell}

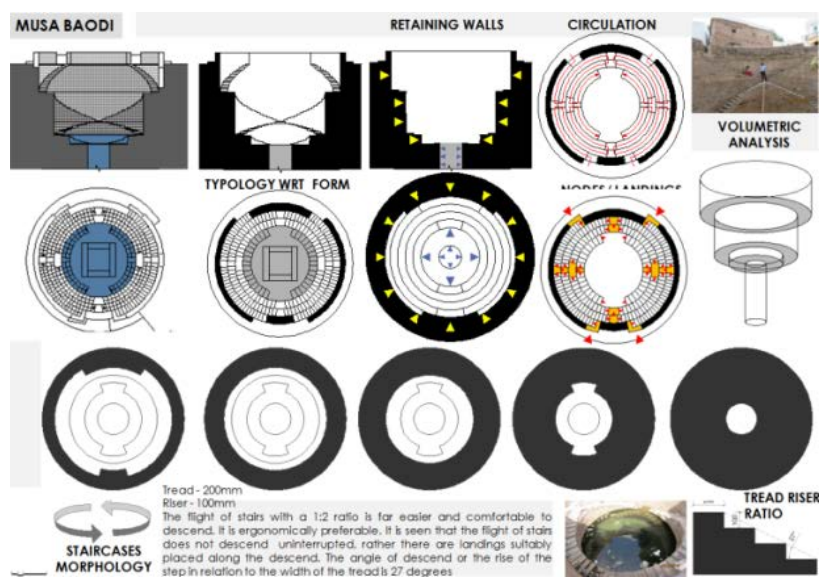

Fig. 2: Drawing of Musa Step Well, Chanderi

Form-The architectural ground plan of Musa step well is simple admeasuring $9.55 \mathrm{~m}$ in diameter. It consists mainly of the shaft of the well, and a short entrance staircase which leads into a spiral stairway. This spiral stairway is attached to the wall of the well and descends downwards.

Circulation- Four intermediate accesses of Musa step well descending towards the water source.

Engineering skills- Circular shape of Musa step well has been employed of great depth as the circle walls are selfsupporting and distribute a lateral force of the surrounding earth. Walls are self-supporting and distribute a lateral force of the surrounding earth.

\section{Qaziyon Stepwell}

Form- The well shaft of Qaziyon step well admeasuring $7.0 \mathrm{~m}$ in diameter is separated from the staircases by arched entrances on opposite sides. This step well looks like a watch in plan hence the local name, 'Ghadi'.

Circulation- In Qaziyon step well, two main flights of steps on opposite side of the well shaft descend downwards.

Engineering skills- The side retaining walls of the trench on opposite sides and the circular self-supporting wall of the well shaft resist the lateral forces or thrust of the surrounding earth of Qaziyon step well.

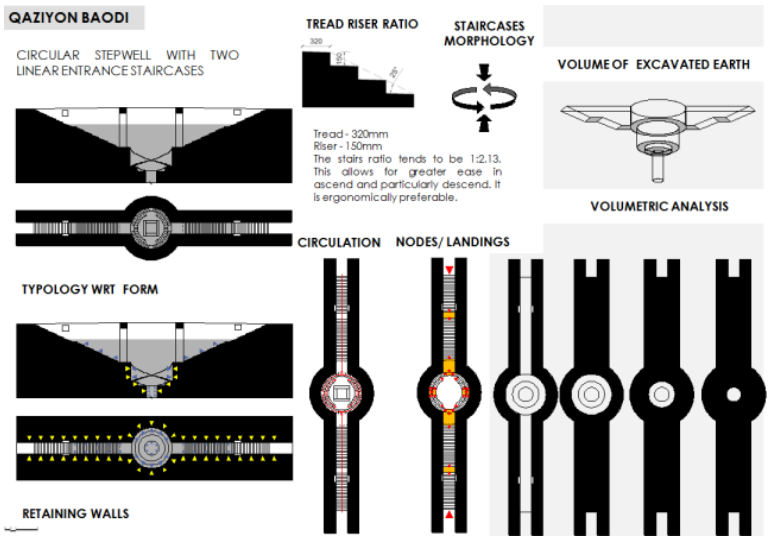

Fig. 3: Drawing of Qaziyon Stepwell, Chanderi

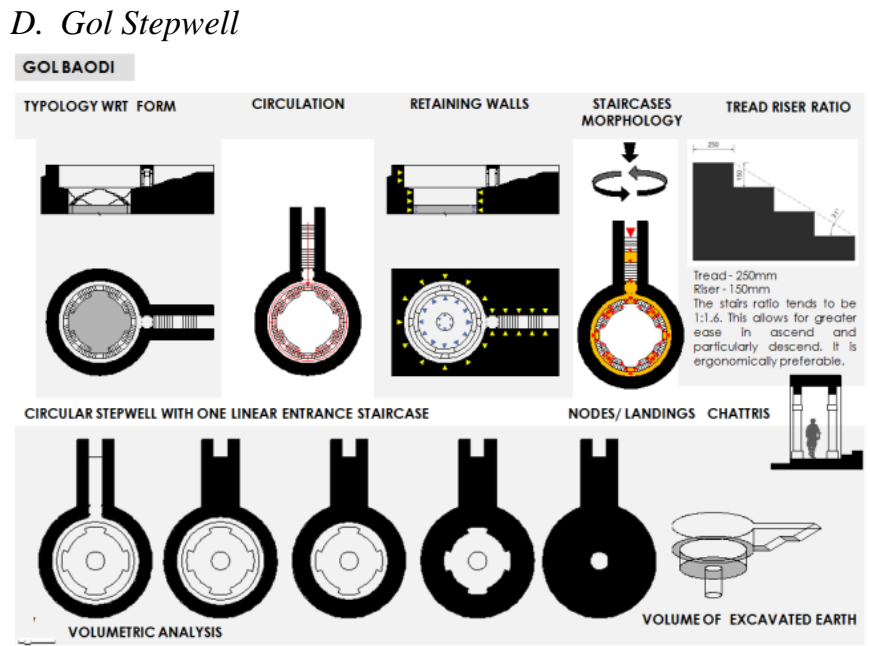

Fig. 4: Drawing of Gol Stepwell,Chanderi

Form- The architectural ground plan of Gol step well is simple admeasuring $12.5 \mathrm{~m}$ in diameter. It consists mainly of the shaft of the well, and a short entrance staircase which leads into a spiral stairway.

Circulation-The addition of lateral and bilateral steps in Gol step well serves as a device to reach more quickly a lower level and reduce the corridor length as compared to the system with parallel descending steps only.

Engineering skills- Circular shape of Gol step well has been employed of great depth as the circle walls are selfsupporting and distribute a lateral force of the surrounding earth. Walls are self-supporting and distribute a lateral force of the surrounding earth.

\section{E. Phool Baug Stepwell}

Form- A small simple square Phool baug stepwell admeasuring $4.5 \mathrm{mX} 5.5 \mathrm{~m}$ has flight of steps on all three sides to descend down. A kiosk is present on the North-East side.

Circulation- Phool baug stepwell has flight of steps on all three sides to descend down to fetch water as well as to retain the walls of the stepwell.

Engineering Skills- Stone masonry retaining walls on all four sides to retain the thrust from the earth.

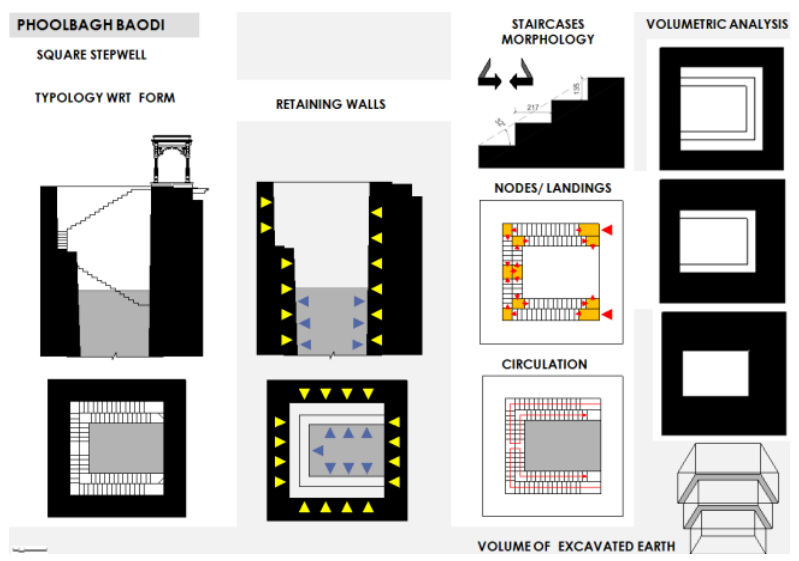

Fig. 5: Drawing of Phoolbaugh Stepwell 


\section{RESULTS}

Architectural study analysis showcased that these water heritage structures vary in size and form types, scales, access and use and the potentiality that they have.

\section{CONCLUSION}

Through the architectural analytic study we can conclude that due to geographical terrain and climatologically factors a range of water conservation techniques evolved in different regions giving rise to various building typologies to conserve water which culminated an interface between spaces, architectural elements, and water. A look into its past records through archives and personal interviews reveals that building of step wells in Chanderi has not only been a stroke of genius by the rulers but also has had different roles to be played in the administration of rulers. A way forward to the study would be to formulate a comprehensive proposal which can be taken up for conservation of water supply system and the urban spatial structure related to it along with development policies at city level and design policies at micro level.

\section{REFERENCE}

[1] R.S.Morwanchikar, “Indian Water Culture”,Pp.1-3,2009.

[2] H.Rima, "Channeling Nature: Hydraulics, Traditional Knowledge Systems, And Water Resource Management in India - A Historical Perspective”, http://www.infinityfoundation.com, Retrieved 19 March 2012.

[3] J.Jutta, "The Stepwells of Delhi”, http://www.delhiheritagecity.org/ $\mathrm{pdfhtml/mughal/jutta-jain-stepwells-delhi-finalpaper,} \mathrm{06Oct2011.}$

[4] B.Mansee, V.Jacko and B.J.Jaap, "Sustainability of Water Resource Systems in India: Role of Value in Urban Lake Governance in Ahmedabad”, Pp.1-29,http://repub.eur.nl/res/pub/26325/.

[5] K.Shubhangi and D.Shireesh, "Stepwells and Stepped ponds: Water responsive Architectonic Forms in Landscape Urbanism”, Refereed Journal of The Indian Institute of Architects, Vol.04, Pp.17-22, April 2014.

[6] K.Priya, "Water Management Systems in the coastal area of Ratnagiri taluka, Ratnagiri district, Maharashtra: with sp. Ref. to Water tanks near the Temples”, http://www.indiawaterportal.org/post/13508, Retrieved 5 March 2012.

[7] K.Swati and M.Arif, "Wetland Management and Planning: Issues and Application", Abacus An internationally refereed Bi-Annual Journal of Architecture, Conservation and Urban Studies, Vol.2,Number1,Pp.8296,Spring 2007.

[8] K.Hasan-Uddin, "Architectural Conservation as a tool for Cultural Continuity: A Focus on the Built Environment of Islam", International Journal of Architectural Research,Vol.9, Issue 1,Pp.1-17, March 2015.

[9] K.Bashir, "Sustainable urban design paradigm: Twenty five simple things to do to make an urban neighbourhood sustainable", Retrieved faculty.headroyce.org.

[10] D.Keshab and S.Pritee, "Reviving a Water Heritage: Economic and Environmental Performance of Traditional Water Harvesting Systems in Western India,www.rainwaterharvesting.org.

[11] R.Sureshkumar, "Assessing the role of groundwater in Urban Development and Planning-Case study of NCT Delhi”, Abacus An internationally refereed Bi-Annual Journal of Architecture, Conservation and Urban Studies, Vol.2,Number1,Pp.69-80,Spring 2007.

[12] Y.Mugdha, "Architectural Heritage Management through Community Engagement", Refereed Journal of The Indian Institute of Architects, Vol.78,Issue 6,Pp.23-27, June 2013.

[13] M.S.Mate, in Badam,G.L;Chakravarty,K.K;Paranjpe,V. (Ed), “Traditional Water Management Systems of India”,Pp.25-33,2006.

[14] A.Anil and N.Sunita, "Dying Wisdom”, Pp.27,1997.

[15] K. Shubhangi and D. Shireesh, "Role of traditional water related architecture in Chanderi-Madhya Pradesh India", International Conference on Evolution in Engineering and Management,Pp.390-394, 30-31January2015.
[16] City Develoment Plan of Various Urban Local Bodies of Madhya Pradesh, Pp.59 ,www.e-mpcdp.com/ECDP/CDP-Chanderi-E-pdf.

\section{AUTHOR BIOGRAPHY}

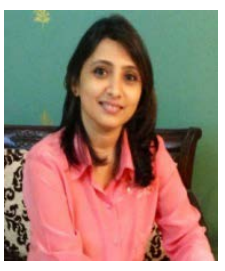

K.Shubhangi was born in Pune, Maharashtra. She received her Bachelor in Architecture degree with First Class from Pune University, Maharashtra, India ,in 1996 and successfully completed M.Tech degree with First Class and Distinction in Town and Country Planning from Govt. College of Engineering, Pune University, Maharashtra, India, in 2005. At present she is working as an Associate Professor in Marathwada Mitramandal's College of Architecture, Pune, Maharashtra, India,

Her areas of interest include Research and spreading awareness in Heritage Conservation. She is currently pursuing her doctoral study on 'Traditional water related architecture in urban areas of India' under the guidance of Prof.Emeritus. D.Shireesh and has been engaged in teaching, research and practice. She is a member of National Scientific Committees of The International Council on Monuments and Sites, India.(ICOMOS).She has specifically worked on Environmental Status Report 2003-'04 for Pune Municipal Corporation,Maharashtra, India.

She is an Associate Member of professional bodies- Institute of Town Planners, India and Indian Institute of Architects.

She has written research papers and has presented in various seminars and conferences for which has also received best paper award by Indians Building Congress.

Contact Details- Ms.Shubhangi Sharadchandra Kadam.

C/o Mr Abhayraj Shirole,Vishwakamal Apartments,Vimlabai Jadhav Road,32-Shivajinagar,

City-Pune-411005,State: Maharashtra,Country: India.

Mobile +919881600001.

E-mail: shubhangikadam12873@gmail.com, shiroleys@gmail.com.

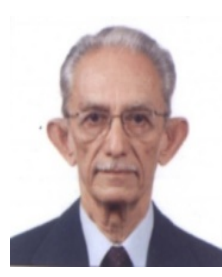

Prof.Emeritus. D.Shireesh studied Architecture at the Sir J J School of Art, Bombay - 1951 to 1956.He passed the Royal Institute of British Architects (R I B A) London Examination in 1957.He completed his Post Graduate Diploma in Town \& Country Planning at School of Architecture and Planning, New Delhi 1957 to 1959.Studied at the BOUWCENTRUMRotterdam, International Course in Building 1962 1963.He was President of the Indian Institute of Architects for the Term 1992 - 94. He was an Indian Institute of Architects Official Delegate to ARCASIA in Kuala Lumpur, Bangkok, Seoul, New Delhi , Singapore and Hong Kong 1977 to 1993.He was Former Professor and Head of the Department of Architecture at the Visvesvaraya Regional College of Engineering, Nagpur, Maharashtra, India.

Contact Details- Prof. S A Deshpande, 88, West Park Road, Dhantoli, Nagpur ; 440012 India.

Mobile : +91 9096022752

E-mail: profsad@gmail.com 